\title{
Pengaruh Kepercayaan Manajerial, Orientasi Jangka Pendek, dan Iklim Kerja Etis Terhadap Senjangan Anggaran
}

\author{
Clara Yunneke Tanadi ${ }^{1}$ \\ Fakultas Ekonomi dan Bisnis \\ Universitas Udayana, Indonesia \\ Email: clarayunneketanadi1598@gmail.com
}

\author{
Ni Putu Sri Harta Mimba ${ }^{2}$ \\ Fakultas Ekonomi dan Bisnis \\ Universitas Udayana, Indonesia
}

\begin{abstract}
ABSTRAK
Penelitian bertujuan untuk menguji pengaruh kepercayaan manajerial, orientasi jangka pendek, dan iklim kerja etis terhadap senjangan anggaran. Senjangan anggaran merupakan selisih pendapatan dan beban yang telah dianggarkan dengan perkiraan yang mampu diperoleh. Lokasi penelitian dilakukan di Dinas Tenaga Kerja dan Energi Sumber Daya Mineral Provinsi Bali. Metode penentuan sampel yang digunakan adalah nonprobability sampling dengan cara sensus atau sampling total. Metode pengumpulan data yang digunakan metode survei dengan menyebarkan kuesioner yang jumlah responden sebanyak 80 orang. Teknik analisis data yang digunakan adalah analisis regresi linear berganda. Hasil penelitian yang diperoleh adalah kepercayaan manajerial berpengaruh negatif terhadap senjangan anggaran, orientasi jangka pendek berpengaruh positif terhadap senjangan anggaran, dan iklim kerja etis tidak berpengaruh terhadap senjangan anggaran.
\end{abstract}

Kata Kunci: Kepercayaan Manajerial; Orientasi Jangka Pendek; Iklim Kerja Etis; Senjangan Anggaran.

\section{The Effect of Managerial Trust, Short-term Orientation, Ethical Work Climate on Budgetary Slack}

\begin{abstract}
The research aims to examine the effect of managerial trust, short-term orientation, and ethical work climate on budgetary slack. Budgetary slack is the difference between budgeted revenues and expenses with estimates that can be obtained. The location of the study was conducted at the Office of Labor and Energy of Mineral Resources in Bali Province. The sampling method used is nonprobability sampling by census or total sampling. Data collection methods used survey methods by distributing questionnaires with 80 respondents. The data analysis technique used is multiple linear regression analysis. The results obtained are managerial trust negatively affect budgetary slack, shortterm orientation has a positive effect on budgetary slack, and ethical work climate has no effect on budgetary slack.
\end{abstract}

Keywords: $\quad$ Managerial Trust; Short-term Orientation; Ethical Work Climate; Budgetary Slack.

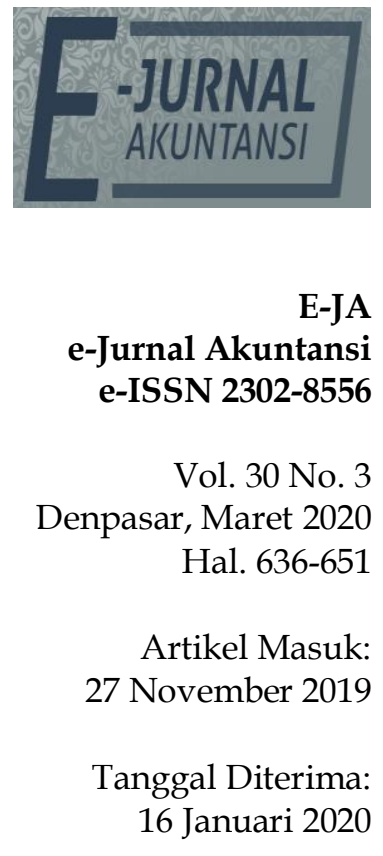




\section{PENDAHULUAN}

Organisasi memiliki pilar dalam penyusunan program atau rencana yang berperan sebagai pencapaian tujuan. Program atau rencana kerja memuat sasaran capaian kerja dan anggaran yang diperlukan untuk satu tahun ke depan. Anggaran menjadi acuan utama untuk organisasi tersebut dalam menjalankan kegiatannya guna pencapaian tujuan organisasi. Anggaran berisikan perencanaan keuangan dalam bentuk pendapatan dan belanja. Proses perencanaan dan pengendalian dalam suatu organisasi menggunakan anggaran sebagai komponen terpenting (Hansen \& Mowen, 2011:423). Penilaian prestasi pimpinan organisasi, pengendalian, komunikasi, koordinasi, serta sebagai alat motivasi merupakan fungsi anggaran (Kenis, 1979 dalam Ariawan et al., 2015). Menurut Okafor \& Otalor (2018) anggaran juga dapat dinyatakan sebagai rencana mengalokasikan sumber daya di antara kebutuhan yang bersaing.

Sejak awal era reformasi pemerintah di Indonesia sudah menganut asas desentralisasi yang memberikan kebebasan dan keleluasan kepada pemerintah daerah dalam menyelenggarakan pemerintahan melalui otonomi daerah. Otonomi daerah bertujuan untuk mempercepat terwujudnya kesejahteraan masayarakat dengan upaya peningkatan, pelayanan, pemberdayaan, dan peran serta masayarakat (Puspitha \& Suardana, 2017). Perubahan sistem anggaran pada manajemen keuangan daerah yang disebabkan oleh pemberlakuan otonomi daerah. Perubahan sistem anggaran adalah perubahan metode anggaran berbasis konvensional menjadi sistem anggaran berbasis kinerja (Suherman \& Dewi, 2019). Sistem penganggaran berbasis kinerja mengemukakan capaian hasil kerja yang diukur dengan indikator output, hasil manfaat dan dampak sehingga pertimbangan kemanfaatan bagi masyarakat dapat diperhatikan (Kartiwa, 2004).

Kusuma (2014) menyatakan penyusunan anggaran sektor publik dimulai dari setiap OPD menyusun Rencana strategis (Renstra) yang berisikan rencana kerja (Renja) tahunan selama lima tahun berdasarkan Rencana Pembangunan Jangka Menengah (RPJMD) yang memuat tentang visi dan misi Gubernur yang terpilih selama lima tahun. Renstra tersebut akan diperiksa kembali oleh Badan Perencanaan dan Pembangunan Daerah (BAPPEDA) serta dimusyawarahkan oleh setiap Kepala OPD dan tokoh-tokoh masyarakat. Hasil musyawarah adalah Kebijakan Umum Anggaran (KUA) dan rancangan Prioritas Plafon Anggaran Sementara (PPAS). KUA dan PPAS akan disampaikan dan dibahas oleh Gubernur kepada DPRD yang akan menghasilkan RKA (Rencana Kerja Anggaran) OPD. RKA akan diverifikasi oleh tim anggaran yang terdiri dari Badan Pengelolaan Keuangan dan Aset Daerah (BPKAD) dan BAPPEDA. Setelah diverifikasi akan dihasilkan Rencana Anggaran Pendapatan dan Belanja Daerah (RAPBD) yang dibahas oleh Gubernur dan DPRD, dan turunlah Peraturan RAPBD. Peraturan RAPBD berisi penjabaran anggaran untuk setiap OPD. Setiap penjabaran APBD terdapat Dokumen Pelaksana Anggaran OPD (DPA OPD).

Organiasi sektor publik dalam menyusun anggaran berpedoman dengan konsep value for money untuk menghindari penilaian inefisiensi, pemborosan, sumber kebocoran dana, dan instansi yang selalu merugi. Konsep value for money menurut Mardiasmo (2018:5-6) merupakan konsep pengelolaan organisasi sektor publik yang mendasarkan pada tiga elemen utama yaitu ekonomi, efisiensi, dan efektivitas serta dua tambahan elemen lain yakni keadilan (equity) dan 
kesetaraan (equality). Ekonomi artinya organisasi sektor publik dapat menghindari pengeluaran yang boros dan tidak produktif. Efisiensi memiliki makna perbandingan output atau input yang dikaitkan dengan standar kinerja atau target yang telah ditetapkan. Efektivitas memiliki arti sebagai tingkat pencapaian hasil program dengan target yang ditetapkan. Keadilan (equity) mengacu pada adanya mendapatkan pelayanan publik yang berkualitas dan kesejahteraan ekonmi. Kesetaraan (equality) artinya penggunaan uang publik tidak hanya terkonsentrasi pada kelompok tertentu saja, melainkan dilakukan secara merata.

Tabel 1. Laporan Realisasi Pendapatan dan Belanja Dinas Tenaga Kerja dan Energi Sumber Daya Mineral Provinsi Bali Tahun 2016-2018

\begin{tabular}{|c|c|c|c|c|}
\hline Tahun & Uraian & Anggaran (Rp) & Realisasi (Rp) & Selisih (Rp) \\
\hline \multirow{5}{*}{2016} & Pendapatan & 22.945 .225 .000 & 23.296 .123 .080 & 350.898 .080 \\
\hline & Belanja Tidak & 21.572.798.903 & 19.082.968.998 & (2.489.829.905) \\
\hline & Langsung & & & \\
\hline & Belanja & 14.503.987.087 & 14.037.965.745 & $(466.021 .342)$ \\
\hline & Langsung & & & \\
\hline \multirow{4}{*}{2017} & Pendapatan & 18.227.250.000 & 16.754 .626 .525 & $(1.472 .623 .475)$ \\
\hline & Belanja Tidak & 24.145.937.995 & 20.706.148.628 & (3.439.789.367) \\
\hline & Langsung & & & \\
\hline & $\begin{array}{l}\text { Belanja } \\
\text { Langsung }\end{array}$ & 26.320.574.532 & 23.020 .202 .980 & (3.300.371.552) \\
\hline \multirow{4}{*}{2018} & Pendapatan & 500.000 .000 & 569.900 .000 & 69.900 .000 \\
\hline & Belanja Tidak & 22.287 .948 .516 & 21.580 .503 .138 & (707.445.378) \\
\hline & Langsung & & & \\
\hline & $\begin{array}{l}\text { Belanja } \\
\text { Langsung }\end{array}$ & 33.998.292.614 & 18.439.911.877 & (15.558.380.737) \\
\hline
\end{tabular}

Sumber: Dinas Tenaga Kerja dan Energi Sumber Daya Mineral Provinsi Bali, 2019.

Konsep value for money belum diterapkan pada saat merancang anggaran jika suatu keadaan disebabkan oleh adanya wujud pemasukkan yang lebih besar atau ketepatgunaan belanja sehingga menghasilkan Selisih Lebih Pembiayaan Anggaran (SILPA) (Widanaputra \& Mimba, 2014). SILPA dapat menilai kinerja pejabat baik karena, telah melaksanankan kegiatan dengan pencapaian yang melebihi target serta pengeluaran yang dilakukan untuk membiayai kegiatan tersebut lebih rendah dari yang direncanakan. Tercapainya target suatu anggaran membuat kinerja pejabat tersebut terlihat baik. Pejabat akan menghindari tidak tercapainya suatu target anggaran dengan menciptakn budgetary slack pada saat menyusun anggaran.

Budgetary slack atau lebih dikenal dengan senjangan anggaran dibuat oleh individu dengan cara memperkirakan pengeluaran suatu biaya yang lebih tinggi serta pemasukkan suatu pendapatan yang disusun lebih rendah (Hobson et al., 2011). Budgetary slack dilakukan agar pendapatan yang dicapai sesuai dengan atau melebihi target serta belanja yang dikeluarkan lebih sedikit dari yang direncankan (Harvey, 2015). Budgetary slack timbul akibat upaya melindungi diri dari risiko tidak tercapainya target anggaran (Astuti et al., 2017). Budgetary slack terjadi pada saat agent berpatisipasi dalam proses penganggaran yang menimbulkan implementasi anggaran tidak dapat berjalan sesuai kapasitas lembaga (Sukayana \& Putri, 2019). 
Teori Keagenan dapat dikaitkan dengan konsep budgetary slack. Jensen \& Meckling (1976) menjelaskan teori keagenan sebagai hubungan kontraktual antara principal yang memberikan mandat atau kewenangan kepada agent yang akan melakukan kewenangan yang diberikan oleh principal sebagai pengambilan keputusan. Principal adalah Kepala Daerah atau Gubernur dan Kepala OPD selaku agent dalam organisasi sektor publik. Hubungan keagaenan antara principal dan agent dapat menimbulkan suatu masalah dalam penganggaran dikarenakan memiliki tujuan yang berbeda. Masalah yang timbul adalah asimetri informasi yang mana agent mengungkapkan pendapatan yang lebih rendah dan biaya yang lebih tinggi. Hal ini mengakibatkan program perencanaan dapat tercapai. Selain target dapat lebih mudah tercapai, agent melakukan budgetary slack agar penilaian kinerja terlihat bagus (Yilmaz et al., 2014). Agent diasumsikan akan menerima kepuasaan tidak hanya dari kompensasi keuangan, tetapi juga dari kondisi kerja yang baik, jam kerja yang fleksibel, dan sebagainya. Principal diasumsikan hanya tertarik pada pengembalian keuangan yang diperoleh dari investasi mereka (Novitasari \& Wirama, 2016).

Jensen \& Meckling (1976) menyatakan teori keagenan merupakan sebagai hubungan kontraktual antara satu atau lebih yang bertindak sebagai principal (pemegang saham) yang menunjuk orang lain sebagai agent (manajer) untuk melakukan beberapa jasa untuk kepentingan principal termasuk mendelegasikan kekuasaan dalam pengambilan suatu keputusan. Pihak principal maupun pihak agent merupakan dua economic agent yang berusaha memaksimalkan utilitasnya. Masing-masing pihak principal maupun agent akan melakukan trade off antara rencana atau anggaran yang diusulkan dengan potensial aktual yang seharusnya dengan cara menyimpan informasi privatnya atau asimetri informasi.

Kepercayaan manajerial menurut Chong \& Ferdiansah (2014) merupakan keyakinan bawahan terhadap atasan dapat diandalkan dan tidak akan mengambil keuntungan dari mereka. Kepercayaan manajerial dalam organisasi menimbulkan hubungan kooperatif antara principal dan agent yang menyebabkan adanya pertukaran informasi antara principal dengan agent, maka akan mengurangi ketidakseimbangan informasi (Jones, 1995). Berkurangnya informasi yang disimpan secara privateakan menurunkan kecendrungan budgetary slack dalam organisasi tersebut. Hal ini akan menunjukkan perilaku yang mengutamakan organisasi diatas kepentingan individu. Bukti empiris ini didukung oleh Young (1985) dan Maiga \& Jacobs (2007) yang menyatakan bahwa semakin tinggi kepercayaan manajerial, semakin rendah kecendrungan dalam menciptakan budgetary slack.

$\mathrm{H}_{1}$ : Kepercayaan manajerial berpengaruh negatif terhadap budgetary slack.

Berdasarkan agency theory, agent dengan principal memiliki masalah keagenan yang disebabkan perbedaan tujuan. Dalam siklus penganggaran bersifat konsisten yaitu menyusun anggaran dengan periode satu tahun atau secara orientasi jangka pendek. Hal ini akan membuat agent melakukan perilaku yang disfungsional yakni menciptakan slack pada anggaran. Laverty (1996) mengungkapkan bahwa penyusun anggaran yang berfokus pada orientasi jangka pendek digunakan untuk memperbaiki kinerjanya di masa lalu untuk memaksimalkan insentif moneter mereka sendiri. 
Pejabat penyusun anggaran juga menunjukkan moral hazard yaitu mengejar hasil yang lebih cepat, baik karena itu pilihan yang minim risiko di jangka pendek atau karena insentif jangka panjang tidak cukup. Budgetary slack yang diciptakan pada masa orientasi jangka pendek memiliki beberapa keuntungan. Slack pada anggaran dapat meningkatkan probabilitas bahwa target anggaran akan tercapai sehingga meningkatkan kemungkinan menerima evaluasi yang menguntungkan (terkait dengan imbalan dan kinerja). Slack sebagai sarana perlindungan dari potensi ketidakpastian di masa depan sehingga dalam organisasi yang memperlakukan anggaran sebagai komitmen yang kuat untuk mencapai tujuan utama organisasi akan menggunakan anggaran sebagai alat untuk mengevaluasi kinerja manajemen. Penelitian dilakukan Dunk (1993), Merchant (1985), Murdijaningsih (2003), Novitasari \& Wirama (2016) menyatakan bahwa budgetary slack juga dapat mendorong manajer untuk lebih berorientasi pada hasil jangka pendek dengan mengesampingkan tujuan organisasi pada jangka panjang.

$\mathrm{H}_{2}$ : Orientasi jangka pendek berpengaruh positif terhadap budgetary slack.

Hubungan keagenan antara principal dengan agent bisa menimbulkan masalah yakni, asimetri informasi dan konflik kepentingan. Organisasi dibentuk untuk mencapai tujuan yang telah direncanakan. Untuk mencapai tujuan diperlukannya perencanaan yang berupa anggaran. Proses penganggaran bisa menimbulkan perilaku disfungsional seperti budgetary slack. Budgetary slack diciptakan karena agent menyembunyikan informasi yang sesungguhnya dari pihak principal dan adanya ketidaksamaan tujuan antara principal dengan agent. Iklim kerja etis dapat menurunkan kecendrungan menciptakan budgetary slack pada saat menyusun anggaran. Iklim kerja etis menurut Victor \& Cullen (1988) adalah kebijakan-kebijakan dan prosedur-prosedur organisasi yang khusus berisi nilai-nilai etis.

Melakukan budgetary slack berarti agent telah melakukan tindakan untuk kepentingan dirinya sendiri bukan atas kepentingan organisasi. Agent berusaha bagaimana membuat semua target dengan mudah dicapai sehingga penilaian kinerja manajer menjadi baik dengan mengabaikan kepentingan organisasi yang lebih besar. Budgetary slack merupakan perilaku yang tidak etis yang dipengaruhi oleh keadaan individu maupun lingkungan (Munandar, et al., 2019). Diantara \& Wirajaya (2017) serta Özera \& Yilmaz (2011) mengungkapkan dengan adanya iklim kerja etis, maka dapat mengurangi perilaku tidak etis yakni kecendrungan dalam menciptakan budegetary slack. Iklim kerja etis juga akan meningkatkan keselarasan tujuan anggaran sehingga budgetary slack yang diciptakan akan menurun (Anthony \& Govindarajan, 2007).

$\mathrm{H}_{3}$ : Iklim kerja etis berpengaruh negatif terhadap budgetary slack.

\section{METODE PENELITIAN}

Penelitian ini menggunakan metode kuantitatif yang berbentuk asosiatif. Metode pengumpulan data menggunakan metode survei dengan cara menyebarkan kuesioner. Teknik penentuan sampel dalam penelitian ini menggunakan nonprobability sampling dengan cara sensus atau sampling total. Penelitian dilaksanakan di Dinas Tenaga Kerja dan Energi Sumber Daya Mineral Provinsi Bali. Responden dalam mengisi kuesioner adalah kepala dinas, sekretaris, kepala 
bidang, kepala sub bagian, kepala seksi, kepala upt, staf keuangan, dan kelompok jabatan fungsional. Jumlah responden sebanyak 80 orang.

Budgetary slack didefinisikan sebagai perbedaan realisasi anggaran pendapatan dan belanja dengan pendapatan dan biaya yang direncanakan, di mana pendapatan yang direncanakan sangat rendah dan biaya yang direncanakan sangat tinggi agar pada saat pencapaian bisa melebihi dari target untuk sisi pendapatan dan realisasi dari sisi belanja bisa di bawah dari target yang direncanakan. Pengukuran budgetary slack menggunakan instrument yang diadopsi dari Dunk (1993). Instrumen penelitian ini terdiri dari enam indikator pernyataan dengan menggunakan Skala Likert lima poin.

Definisi kepercayaan manajerial adalah adanya keyakinan bawahan terhadap atasan dalam menjalankan tugas dan bisa menyelesaikan sebuah persoalan dengan baik. Instrumen penelitian yang digunakan dalam mengukur kepercayaan manajerial adalah mengadopsi penelitian yang dikembangkan oleh Maiga \& Jacobs (2007). Indikator pernyataan kepercayaan manajerial berjumlah empat indikator dengan Skala Likert lima poin.

Orientasi jangka pendek merupakan sejauh mana manajer berfokus dalam urusan organisasi yang akan mempengaruhi penyelenggaraan organisasi selama periode penganggaran saat ini (1 tahun). Instrumen orientasi jangka pendek diadopsi dari penelitian yang dilakukan oleh Marginson et al., (2009). Indikator pernyataan terdiri dari dua bagian yaitu bagian jangka pendek dan mewakili jangka panjang serta diukur dengan Skala Likert lima poin.

Iklim kerja etis didefinsikan sebagai iklim organisasi yang berisikan anggota organisasi memiliki kode etik dalam bekerja, anggota organisasi juga saling menghargai antar satu sama lain, anggota organisasi juga harus mematuhi peraturan-peraturan yang ada di organisasi, selalu mementingkan kepentingan organisasi, serta anggota organisasi memiliki prinsip-prinsip yang benar dalam menjalankan aktivitas di organisasi tersebut. Instrumen penelitian ini adalah instrumen yang dikembangkan oleh Özera \&Yilmaz (2011). Instrumen ini terdiri dari lima indikator pernyataan yang diukur dengan Skala Likert lima poin.

Teknik analisis data yang digunakan dalam penelitian ini adalah statistik deskriptif, uji asumsi klasik, analisis regresi linear berganda, uji koefisien determinasi $\left(\mathrm{R}^{2}\right)$, uji kelayakan model (uji F), dan uji hipotesis (uji t). Rancangan model regresi yang digunakan dalam penelitian ini:

$Y=\alpha+\beta_{1} X_{1}+\beta_{2} X_{2}+\beta_{3} X_{3}+\varepsilon$.

Keterangan:

$$
\begin{array}{ll}
\mathrm{Y} & =\text { Budgetary Slack } \\
\mathrm{a} & =\text { Konstanta } \\
\beta_{\mathrm{i}} & =\text { Koefisien Regresi, } \mathrm{i}=1,2,3 \\
\mathrm{X}_{1} & =\text { Kepercayaan Manajerial } \\
\mathrm{X}_{2} & =\text { Orientasi Jangka Pendek } \\
\mathrm{X}_{3} & =\text { Iklim Kerja Etis } \\
\varepsilon & =\text { Standard Error }
\end{array}
$$

\section{HASIL DAN PEMBAHASAN}

Data penelitian dikumpulkan dengan cara menyebarkan kuesioner kepada 80 responden. Responden terdiri dari kepala dinas, sekretaris, kepala bidang, kepala 
sub bagian, kepala seksi, kepala UPT, staf keuangan, dan kelompok jabatan fungsional. Kuesioner disebarkan pada tanggal 26 September 2019 dan kuesioner yang terjawab diserahkan pada tanggal 4 Oktober 2019. Kuesioner yang disebarkan sebanyak 80 kuesioner dan kuesioner yang kembali sebanyak 75 kuesioner. 75 kuesioner terdiri dari 9 kuesioner yang tidak lengkap serta kuesioner yang layak digunakan sebanyak 66 kuesioner. Kuesioner yang tidak dikembalikan sejumlah lima kuesioner.

Uji instrumen pada kuesioner terdiri dari uji validitas dan uji reliabilitas. Kuesioner yang disebarkan menghasilkan nilai valid tiap pernyataan dari variabel kepercayaan manajerial, orientasi jangka pendek, iklim kerja etis, dan budgetary slack. Nilai valid didukung jika nilai koefisien korelasi yang dihasilkan lebih besar dari 0,30. Variabel kepercayaan manajerial, orientasi jangka pendek, iklim kerja etis, dan budgetary slack memperoleh nilai reliabel. Suatu pernyataan variabel dinyatakan reliabel jika nilai Croanbach's Alpha lebih besar dari 0,70.

Tabel 2. Hasil Statistik Deskriptif

\begin{tabular}{lccccc}
\hline \multicolumn{1}{c}{ Variabel } & N & Min. & Maks. & $\begin{array}{c}\text { Rata- } \\
\text { rata }\end{array}$ & $\begin{array}{c}\text { Deviasi } \\
\text { Standar }\end{array}$ \\
\hline Budgetary Slack $(\mathrm{Y})$ & 66 & 12,00 & 26,00 & 18,66 & 2,70 \\
Kepercayaan Manajerial $\left(\mathrm{X}_{1}\right)$ & 66 & 4,00 & 18,00 & 13,72 & 2,62 \\
Orientasi Jangka Pendek $\left(\mathrm{X}_{2}\right)$ & 66 & 0,00 & 1,00 & 0,54 & 0,50 \\
Iklim Kerja Etis $\left(\mathrm{X}_{3}\right)$ & 66 & 10,00 & 25,00 & 19,06 & 2,54 \\
\hline
\end{tabular}

Sumber: Data Penelitian, 2019

Berdasarkan Tabel 2. dapat disimpulkan bahwa jumlah pengamatan (N) pada penelitian ini adalah sebanyak 66 . Variabel budgetary slack $\left(\mathrm{X}_{1}\right)$ memiliki nilai minimum sebesar 12,00 dan nilai maksimum 26,00 dengan nilai rata-rata sebesar 18,66. Hal ini menunjukkan bahwa respon responden dalam menjawab pernyataan pada kuesioner cenderung merasa setuju pada masing-masing item pernyataan yang memiliki arti budgetary slack cenderung tinggi. Deviasi standar pada variabel budgetary slack adalah sebesar 2,70 yang menunjukkan bahwa standar penyimpangan data terhadap nilai rata-ratnya adalah 2,70.

Variabel kepercayaan manajerial $\left(\mathrm{X}_{1}\right)$ memiliki nilai minimum sebesar 4,00 dan milai maksimum 18,00 serta nilai rata-rata sebesar 19,06. Nilai rata-rata sebesar 19,06 menunjukkan bahwa respon responden dalam menjawab pernyataan pada kuesioner cenderung merasa setuju pada masing-masing item pernyataan artinya kepercayaan manajerial cenderung tinggi. Deviasi standar pada variabel kepercayaan manajerial adalah 2,62 yang memiliki arti bahwa standar pernyimpangan data terhadap nilai rata-ratanya sebesar 2,62.

Variabel orientasi jangka pendek $\left(\mathrm{X}_{2}\right)$ merupakan variabel dummy yang memiliki nilai minimum sebesar 0,00 dan nilai maksimum 1,00 serta rata-rata yang dimiliki sebesar 0,54 . Nilai rata-rata 0,54 yang mendekati nilai maksimum mempunyai arti bahwa respon responden cenderung setuju terhadap masingmasing item pernyataan sehingga menyebabkan orientasi jangka pendek cenderung tinggi. Orientasi jangka pendek memiliki deviasi standar sebesar 0,50 yang memiliki arti bahwa standar penyimpangan data terhadap nilai rataratanya adalah 0,50 .

Variabel iklim kerja etis $\left(X_{3}\right)$ memiliki nilai minimum sebesar 10,00 dan nilai maksimum sebesar 25,00 dengan nilai rata-ratanya sebesar 19,06. Nilai rata- 
rata 19,06 menunjukkan bahwa repon responden dalam menjawab pernyataan pada kuesioner cenderung merasa setuju pada masing-masing item pernyataan yang artinya iklim kerja etis cenderung tinggi. Deviasi standar pada variabel iklim kerja etis adalah sebesar 2,54 yang artinya standar penyimpangan data terhadap nilai rata-ratanya adalah 2,54 .

Informasi yang menyatakan variabel bebas dari asumsi-asumsi yang bersifat BLUE (Best, Linear, Unbiased, Estimator) diketahui melalui uji asumsi klasik. Uji asumsi klasik ini terjadi sebelum meguji analisis regresi linear berganda. Penelitian ini menggunakan uji asumsi klasik yang terdiri dari uji normalitas, uji multikolinearitas, dan uji heteroskedastisitas.

Tabel 3. Hasil Uji Normalitas

\begin{tabular}{cc}
\hline Kolmogorv-Smirnov & Unstandaridized Residual \\
\hline $\mathrm{N}$ & 66 \\
Asymp. Sig. (2-tailed) & 0,502 \\
\hline
\end{tabular}

Sumber: Data Penelitian, 2019

Uji normalitas digunakan untuk mengetahui penyebaran data penelitian terdistribusi normal. Pada penelitian ini uji normalitas yang dihasilkan data dalam penelitian ini terdistribusi normal. Hal ini didukung dengan Asymp. Sig 2tailed yang dihasilkan adalah 0,502 lebih besar dari level of significant 0,05.

Tabel 4. Hasil Uji Multikolinearitas

\begin{tabular}{lccc}
\hline \multicolumn{1}{c}{ Variabel } & Tolerance & VIF & Keterangan \\
\hline Kepercayaan Manajerial $\left(\mathrm{X}_{1}\right)$ & 0,971 & 1,030 & Tidak Multikolinearitas \\
Orientasi Jangka Pendek $\left(\mathrm{X}_{2}\right)$ & 0,965 & 1,036 & Tidak Multikolinearitas \\
Iklim Kerja Etis $\left(\mathrm{X}_{3}\right)$ & 0,967 & 1,034 & Tidak Multikolinearitas \\
\hline
\end{tabular}

Sumber: Data Penelitian, 2019

Terdeteksi adanya suatu korelasi antar variabel bebas diperlukan uji multikolinearitas. Tidak terdeteksinya multikolinearitas jika nilai tolerance yang dihasilkan lebih besar dari 0,1 atau VIF kurang dari 10. Variabel kepercayaan manajerial, orientasi jangka pendek, dan iklim kerja etis dalam penelitian ini tidak terjadi multikolinearitas.

Tabel 5. Hasil Uji Heteroskedastisitas

\begin{tabular}{lcc}
\hline \multicolumn{1}{c}{ Variabel } & Sig. & Keterangan \\
\hline Kepercayaan Manajerial $\left(\mathrm{X}_{1}\right)$ & 0,362 & Bebas Heteroskedastisitas \\
Orientasi Jangka Pendek $\left(\mathrm{X}_{2}\right)$ & 0,103 & Bebas Heteroskedastisitas \\
Iklim Kerja Etis $\left(\mathrm{X}_{3}\right)$ & 0,446 & Bebas Heteroskedastisitas \\
\hline
\end{tabular}

Sumber: Data Penelitian, 2019

Bebas heteroskedastisitas jika dalam sebuah model regresi terjadi ketidaksamaan varians dari residual atas satu pengamatan ke pengamatan yang lain. Uji heteroskedastisitas menggunakan uji glejser. Variabel bebas dinyatakan bebas heteroskedastisitas jika nilai signifikansi yang dihasilkan lebih besar dari 0,05. Variabel bebas kepercayaan manajerial, orientasi jangka pendek, dan iklim kerja etis pada penelitian bebas terkandung heteroskedastisitas.

Nilai $R$ square $\left(R^{2}\right)$ pada Tabel 6. menghasilkan 0,656 atau $65,6 \%$. Hal ini menunjukkan bahwa faktor-faktor yang digunakan dalam penelitian ini memiliki pengaruh sebesar $65,6 \%$ terhadap budgetary slack dengan 34,4\% dipengaruhi oleh faktor-faktor lain yang tidak dijelaskan dalam penelitian.

Uji kelayakan model yang dihasilkan oleh Tabel 6. ditunjukkan dengan sig. Fhitung sebesar 0,014 yang mana lebih kecil dari 0,05. Hal ini menandakan 
variabel kepercayaan manajerial $\left(X_{1}\right)$, orientasi jangka pendek $\left(X_{2}\right)$, dan iklim kerja etis $\left(\mathrm{X}_{3}\right)$ berpengaruh secara simultan terhadap budgetary slack.

Tabel 6. Analisis Regresi Linear Berganda

\begin{tabular}{|c|c|c|c|c|c|}
\hline \multirow[t]{2}{*}{ Model } & \multicolumn{2}{|c|}{$\begin{array}{l}\text { Unstandarized } \\
\text { Coefficients }\end{array}$} & \multirow{2}{*}{$\begin{array}{c}\begin{array}{c}\text { Standardized } \\
\text { Coefficients }\end{array} \\
\text { Beta }\end{array}$} & \multirow[t]{2}{*}{$\mathrm{t}$} & \multirow[t]{2}{*}{ Sig. } \\
\hline & $\mathrm{B}$ & Std. Error & & & \\
\hline (Constant) & 0,199 & 0,047 & & 4,24 & 0,000 \\
\hline $\begin{array}{l}\text { Kepercayaan } \\
\text { Manajerial }\end{array}$ & $-0,265$ & 0,122 & $-0,257$ & $-2,168$ & 0,034 \\
\hline $\begin{array}{l}\text { Orientasi } \\
\text { Jangka Pendek }\end{array}$ & 0,022 & 0,010 & 0,266 & 2,244 & 0,028 \\
\hline Iklim Kerja Etis & 0,055 & 0,129 & 0,051 & 0,427 & 0,671 \\
\hline$F_{\text {hitung }}$ & 3,826 & & & & \\
\hline Sig. Fitung & 0,014 & & & & \\
\hline $\mathrm{R}^{2}$ & 0,656 & & & & \\
\hline Adjusted $R^{2}$ & 0,615 & & & & \\
\hline
\end{tabular}

Sumber: Data Penelitian, 2019

Berdasarkan hasil yang diperoleh dari analisis regresi linear berganda ada

Tabel 6. tersebut dapat dibuat persamaan sebagai berikut.

$$
Y=0,199-0,265 X_{1}+0,022 X_{2}+\varepsilon
$$

Hasil uji analisis regresi linear berganda ditunjukkan pada Tabel 6. yang memperoleh $\beta_{1}=-0,265$ dengan nilai $t$ hitung sebesar $-2,1668$ dan tingkat signifikansi uj $\mathrm{t}$ sebesar 0,034 yang menunjukkan angka lebih kecil daripada taraf nyata dalam penelitian ini yaitu sebesar 0,05. Hal ini berarti kepercayaan manajerial memberikan pengaruh negatif pada budgetary slack. Dapat dinyatakan hipotesis pertama $\left(\mathrm{H}_{1}\right)$ yang menyatakan bahwa kemampuan kepercayaam manajerial berpengaruh negatif terhadap budgetary slack pada Dinas Tenaga Kerja dan Energi Sumber Daya Mineral Provinsi Bali diterima.

Hasil penelitian ini sejalan dengan penelitian yang telah dilakukan oleh Chong \& Ferdiansah (2014), Maria \& Nahartyo (2012) yang menyatakan bahwa dengan adanya kepercayaan antara atasan dengan bawahan mengungari tindakan untuk menciptakan slack pada anggaran. Sama halnya dengan Maiga \& Jacobs (2007) yang menyatakan bahwa kepercayaan yang semakin meningkatkan akan menimbulkan dalam menyusun anggaran untuk tujuan organisasi sehingga mengurangi keinginan untuk melakukan budgetary slack.

Kepercayaan manajerial berpengaruh negatif terhadap budgetary slack didukung juga oleh teori keagenan. Hubungan kontraktual antara principal dengan agent menimbulkan masalah keagenan. Salah satu masalah keagenan yakni ketidakseimbangan informasi atau asimetri informasi. Adanya kepercayaan manajerial dalam organisasi akan menghasilkan hubungan kooperatif seperti adanya pertukaran informasi antara agent dengan principal sehingga dalam organisasi tersebut tidak terjadi ketidakseimbangan informasi (Jones, 1995). Kepercayaan manajerial inilah membuat pejabat penyusun anggaran pada Dinas Tenaga Kerja dan Energi Sumber Daya Mineral Provinsi Bali mengurangi dalam menciptakan slack pada anggaran.

Hasil uji hipotesis menunjukkan bahwa orientasi jangka pendek berpengaruh positif terhadap budgetary slack. Hal ini ditunjukkan dari nilai koefisien regresi variabel orientasi jangka pendek yaitu 0,022 dengan nilai $t$ 
hitung sebesar 2,244 dan signifikansi uji t sebesar 0,028 lebih kecil dari 0,05. Hipotesis kedua $\left(\mathrm{H}_{2}\right)$ dalam penelitian ini yang menyatakan bahwa orientasi jangka pendek berpengaruh positif terhadap budgetary slack pada Dinas Tenaga Kerja dan Energi Sumber Daya Mineral Provinsi Bali diterima. Pejabat di Dinas Tenaga Kerja dan Energi Sumber Daya Mineral Provinsi Bali memilih orientasi jangka pendek sebesar 0,54 atau $54 \%$.

Budgetary slack dapat mendorong manajer untuk memperoleh hasil yang berorientasi jangka pendek dengan mengesampingkan tujuan jangka panjang. Hal ini dilakukan dengan cara mengendalikan kinerja akuntansinya dan memaksimalkan profit jangka pendek yang mana agent akan melakukan pembebanan pada profitabilitas jangka panjangnya (Novitasari \& Wirama, 2016). Murdijaningsih (2003) menyatakan bahwa orientasi jangka pendek akan melakukan perilaku disfungsional untuk memperbaiki kinerja di masa lalu. Hal ini disebabkan anggaran digunakan sebagai alat evaluasi kinerja, yang mana dengan target anggaran tercapai sehingga penilaian kinerja dikatakan akan meningkat.

Moral hazard yang terdapat dalam teori keagenan merupakan perilaku oportunistik yang dilakukan agent untuk memperoleh keuntungannya sendiri dan merugikan tujuan organisasi tersebut. Slack pada anggaran akan melindungi terhadap situasi yang tidak terduga, seperti halnya dengan fluktuasi pada masa jangka pendek. Slack yang dibuat oleh agent akan menutupi pembiayaan jika harga di pasar mengalami kenaikan hal ini membuat agent memilih orientasi jangka pendek dalam menyusun anggaran dikarenakan resiko yang dihadapi rendah. Selain itu, pada masa jangka pendek digunakan oleh agent untuk memperbaiki kinerja masa lalunya. Hal ini diindikasikan untuk meningkatkan prestasi yang diukur dari peningkatan kinerja agent tersebut. Agent akan menyusun anggaran di bawah kemampuannya agar dapat direalisasikan lebih mudah.

Hasil uji analisis regresi linear berganda pada Tabel 6. menunjukkan koefisien regresi $\left(\beta_{3}\right)$ sebesar 0,055 yang memilki nilai $t$ hitung sebesar 0427 dengan tingkat signifikansi uji $t=0,671$ yang lebih besar dari 0,05 . Hal ini menunjukkan bahwa variabel iklim kerja etis tidak berpengaruh terhadap budgetary slack. Dapat dinyatakan hipotesis ketiga $\left(\mathrm{H}_{3}\right)$ yang menyatakan bahwa iklim kerja etis berpengaruh negatif terhadap budgetary slack ditolak.

Hasil penelitian ini tidak sejalan dengan penelitian yang dilakukan Özera \& Yilmaz (2011) yang menyatakan bahwa iklim kerja etis berpengaruh negatif terhadap budgetary slack atau semakin tinggi suatu iklim kerja etis maka dapat mengurangi terciptanya slack pada anggaran. Hasil penelitian ini sejalan dengan Laila (2016) yang mengungkapkan bahwa iklim kerja etis tidak berpengaruh terhadap budgetary slack.

Iklim kerja etis menurut Victor \& Cullen (1988) merupakan kebijakankebijakan dan prosedur-prosedur organisasi yang khusus berisikan nilai-nilai etis, serta persepsi-persepsi yang menunjukkan tipe kebijakan dan prosedur organisasi yang memiliki nilai-nilai etis. Dinas Tenaga Kerja dan Energi Sumber Daya Mineral Provinsi Bali belum mempertimbangkan kode etik dan formal dalam penyusunan anggaran. Kode etik dan formal yang dimaksud adalah menjunjung tanggung jawab profesi, memiliki sikap adil dan objektif, memiliki 
moralitas yang tinggi, mempunyai visi misi yang sama dengan wadah profesi, dan mengerti landasan hukum yang digunakan sebagai pijakan dalam melaksanakan pekerjaannya. Sinkronisasi dan sinergitas dalam rangka menyamakan persepsi dan langkah sinergitas program kerja tahun berikutnya antar OPD dengan kinerja OPD yang berkenan merupakan bagian kode etik dan formal yang belum diterapkan dalam penyusunan anggaran pada Dinas Tenaga Kerja dan Energi Sumber Daya Mineral Provinsi Bali.

Tercapainya tujuan organisasi diperlukan dukungan dari masing-masing individu, sehingga dapat terciptanya iklim kerja etis pada organisasi tersebut. Pengambilan keputusan dalam proses penganggaran harus dibuat secara konsisten tanpa adanya bias-bias pribadi dengan menggunakan sebanyak mungkin informasi yang akurat dan mewakili kepentingan-kepentingan anggota organisasi dengan cara-cara yang sesuai dengan nilai-nilai etis dalam organisasi. Implikasi penelitian secara teoritis menjelaskan hasil penelitian ini dapat memberikan tambahan informasi mengenai kepercayaan manajerial, orientasi jangka pendek, dan iklim kerja etis. Teori keagenan menyatakan hubungan principal dengan agent dapat menyebabkan masalah salah satunya ketidakseimbangan informasi atau informasi tersebut disimpan secara pribadi. Kepercayaan manajerial dapat meminimalisir ketidakseimbangan informasi tersebut sehingga dapat mengurangi terciptanya budgetary slack. Kepercayaan manajerial juga dapat meningkatkan hubungan yang kooperatif antara principal dengan agent.

Teori keagenan menyatakan adanya moral hazard yang timbul pada orientasi jangka pendek. Fluktuasi pada orientasi jangka pendek dapat dihindari dengan dilakukanya budgetary slack. Orientasi jangka pendek dapat membuat agent untuk memperbaiki kinerja masa lalunya di masa sekarang sehingga prestasi yang diperoleh dapat meningkat. Penyusunan anggaran belum mempertimbangkan adanya kode etik yang dapat mengurangi tindakan melakukan budgetary slack. Kode etik yang diterapkan akan membuat iklim kerja pada Dinas Tenaga Kerja dan Energi Sumber Daya Mineral Provinsi Bali menjadi lebih kondusif dan etis.

\section{SIMPULAN}

Berdasarkan hasil analisis dan pembahasan yang telah dilakukan mengenai kepercayaan manajerial, orientasi jangka pendek, dan iklim kerja etis pada budgetary slack adalah kepercayaan manajerial berpengaruh negatif terhadap budgetary slack. Kepercayaan manajerial dapat membuat hubungan kooperatif antara agent dengan principal sehingga menyebabkan terjadinya pertukaran informasi antar kedua belah pihak. Ketidakseimbangan informasi atau asimetri informasi akan berkurang dan terciptanya budgetary slack menurun. Orientasi jangka pendek berpengaruh positif terhadap budgetary slack. Pejabat penyusun anggaran dapat menghindari fluktuasi pada jangka pendek dengan melakukan budgetary slack selain itu, pejabat penyusun anggaran dapat memperbaiki kinerja masa lalunya di masa yang sekarang dengan menyusun anggaran di bawah kemampuannya agar bisa dicapai dengan mudah. Iklim kerja etis tidak berpengaruh terhadap budgetary slack. Iklim kerja etis terdiri kode etik dan kebijakan-kebijakan yang telah diatur agar dalam melaksanakan kegiatan sesuai 
dengan prosedur. Hal ini dapat disebabkan Dinas Tenaga Kerja dan Enegeri Sumber Daya Mineral Provinsi Bali belum mempertimbangkan kode etik dan formal dalam menyusun anggaran yang dapat mengurangi tindakan budgetary slack.

Berdasarkan hasil penelitian dan simpulan, maka saran yang dapat disampaikan bagi OPD adalah Hasil penelitian menunjukkan orientasi jangka pendek berpengaruh positif terhadap budgetary slack maka untuk meminimalisir disarankan kepada OPD untuk adanya pengendalian anggaran agar tidak menghambat inovasi jangka panjang instansi serta dalam hal menyusun anggaran pada sisi target anggaran perlu dibuat data terkait potensi pendapatan daerah dan pada sisi target belanja perlu dibuat analisis standar biaya. Selain itu, diharapkan juga untuk memperhatikan konsep value for money dalam mengelola keuangan. Penelitian ini sebagai pembuka peneliti selanjutnya untuk meneliti kembali pengaruh variabel iklim kerja etis terhadap budgetary slack serta memperluas lokasi penelitian.

\section{REFERENSI}

Anthony, R. N., dan Vijay Govindarajan. (2007). Management Control System (12th edition). The McGraw-Hill Companies, Inc Baiman.

Ariawan, I. P. P., Wirakusuma, M. G., dan Ratnadi, N. M. D. (2015). Keadilan Prosedural dan Iklim Kerja Etis sebagai Pemoderasi Pengaruh Partisipasi Penganggaran pada Senjangan Anggaran (Studi Empiris Pada Pemerintah Kabupaten Tabanan). E-Jurnal Ekonomi Dan Bisnis Universitas Udayana, 07(4), 489-500.https://ojs.unud.ac.id/index.php/EEB/article/view/13376

Astuti, S. A. P. P., Wirama, D. G., dan Rasmini, N. K. (2017). Pengendalian Anggaran yang Ketat dan Orientasi Waktu sebagai Pemoderasi Pengaruh Anggaran Partisipatif pada Senjangan Anggaran. E-Jurnal Ekonomi Dan Bisnis Universitas Udayana, 6(2), 619-646. https://ojs.unud.ac.id/index.php/EEB/article/view/24279

Biantara, A., dan Putri, I G.A.M. Asri Dwija. (2014). Pengaruh Kejelasan Sasaran Anggaran, Etika, Dan Kepercayaan Diri Pada Senjangan Anggaran. E-Jurnal Akuntansi Universitas Udayana, 9(2), 385-391. https://ojs.unud.ac.id/index.php/Akuntansi/article/view/9152

Busch, T., dan Gustafsson, O. (2002). Slack in the Public Sector: A comparative analysis of a private and a public enterprise for refuse collection. Public Management Review, 4(2), 167-186. https:// doi.org/10.1080/14616670210130525

Chong, V. K., dan Ferdiansah, I. (2014). The Effect Of Trust-In-Superior And Truthfulness On Budgetary Slack: An Experimental Investigation. In Advances in Management Accounting (Vol.19). https:// doi.org/10.1108/S1474-7871(2011)0000019009

De Cremer, D., Snyder, M., dan Dewitte, S. (2001). The Less I Trust, The Less I Contribute (or Not). European Journal of Social Psychology, 31(February 1999), 93-107.https://onlinelibrary.wiley.com/doi/abs/10.1002/ejsp.34

De Cremer, D., dan Tyler, T. R. (2007). The Effects Of Trust In Authority And Procedural Fairness On Cooperation. Journal of Applied Psychology, 92(3), 639-649. https:/ / doi.org/10.1037/0021-9010.92.3.639 
Diantara, I. K. A., dan Wirajaya, I. G. A. (2017). Iklim Kerja Etis Memoderasi Pengaruh Partisipasi Penganggaran Pada Senjangan Anggaran. E-Jurnal Akuntansi Universitas Udayana, 20(2), 10461072.https://doi.org/https:// doi.org/10.24843/EJA.2017.v20.i02.p07

Dirks, K. T. (1999). The Effects of Interpersonal Trust on Work Group Performance. Journal of Applied Psychology, 84, 445-445. https:// psycnet.apa.org/buy/1999-05190-012

Dunk, A. (1993). The Effect of Budget Emphasis And Information Asymmetry On The Relation Between Budgetary. Accounting Review: A Quarterly Journal of the American Accounting Association, 68(2), 400-410. https://www.jstor.org/stable/248408?seq=1\#page_scan_tab_contents

Eisenhardt, K. M. (1989). Agency Theory: An Assessment and Review. The Academy of Management Review, 14(1), 57-74. https:// doi.org/https:/ / doi.org/10.5465/amr.1989.4279003

Falikhatun, H. (2008). Interaksi Informasi Asimetri, Budaya Organisasi, dan Group Cohesiveness dalam Hubungan Antara Partisipasi Penganggaran dan Budgetary Slack (Studi Kasus pada Rumah Sakit Umum Daerah Se Jawa Tengah). Media Riset Akuntansi, Auditing Dan Informasi, 8(1), 65-84. https:/ / trijurnal.lemlit.trisakti.ac.id/mraai/article/view/743

Hansen, D. R., dan Mowen, M. M. (2011). Akuntansi Manajerial Buku 1 (Edisi 8). Jakarta: Salemba Empat.

Harvey, M. E. (2015). The Effect Of Employee Ethical Ideology On Organizational Budget Slack: An Empirical Examination And Practical Discussion. Journal of $\begin{array}{lllll}\text { Business } \mathcal{E} \text { Economics Research (JBER), } & 13(1),\end{array}$ https:// doi.org/10.19030/jber.v13i1.9084

Hobson, J. L., Mellon, M. J., dan Stevens, D. E. (2011). Determinants of Moral Judgments Regarding Budgetary Slack: An Experimental Examination Of Pay Scheme And Personal Values. Behavioral Research in Accounting, 23(1), 87-107. https:/ / doi.org/10.2308/ bria.2011.23.1.87

Irfan, M., Santoso, B., dan Effendi, L. (2016). Pengaruh Partisipasi Anggaran terhadap Senjangan Anggaran dengan Asimetri Informasi, Penekanan Anggaran dan Komitmen Organisasional sebagai Variabel Pemoderasi. Jurnal Akuntansi Dan Investasi, 17(2), 158-175. https:// doi.org/10.18196/jai.2016.0052.158-175

Jensen, M., dan Meckling, W. (1976). Theory of the firm: Managerial behavior, agency costs, and ownership structure. The Economic Nature of the Firm: A Reader, Third Edition, 283-303. https:/ / doi.org/10.1017/CBO9780511817410.023

Jones, T. M. (1995). Instrumental Stakeholder Theory: a Synthesis of Ethics and Economics. Academy of Management Review, 20(2), 404-437. https:// doi.org/10.5465/amr.1995.9507312924

Kartiwa, H. A. (2004). Proses Penyusunan Anggaran Pendapatan.Makalah.http://pustaka.unpad.ac.id/wpcontent/uploads/2009/05/proses_penyusunan_anggaran_apbd2.pdf

Kusuma, I. G. E. A. (2014). Pengaruh Kejelasan Sasaran Anggaran, Komitmen Organisasi dan Ketidakpastian Lingkungan pada Ketepatan Anggaran. EJournal Ekonomi Dan Bisnis Universitas Udayana, 154-165. 
https:/ / ojs.unud.ac.id/index.php/EEB/article/download/7622/6045

Laila, I. N. (2016). Pengaruh Persepsi Keadilan Prosedural, Iklim Kerja Etis, dan Tekanan Anggaran Terhadap Timbulnya Senjangan Anggaran (Studi Empiris pada BMT di DKI Jakarta dan Tanggerang).Skripsi.Universitas Islam Negeri Syarif Hidayatullah Jakarta.repository.uinjkt.ac.id

Latuheru, B. P. (2006). Pengaruh Partisipasi Anggaran Terhadap Senjangan Anggaran dengan Komitmen Organisasi Sebagai Variabel Moderating. EJurnal Akuntansi Dan Sistem Teknologi Informasi Universitas Kristen Indonesia Maluku-Ambon, $5(1)$, 2438.http://www.ejurnal.unisri.ac.id/index.php/Akuntansi/article/view/11 7

Laverty, K. J. (1996). Economic "Short Termism": The Debate, The Unresolved Issues, adn The Implications for Management Practice and Reserach. The Academy of Management Review, 21(3), 825-860. https:// doi.org/10.2307/259003

Lubis, A. I. (2011). Akuntansi Keperilakuan (Edisi Kedua). Jakarta: Salemba Empat. Maiga, A., dan Jacobs, F. (2007). Budget participations influence on budget slack: the role of fairness perceptions, trust and goal commitment. Journal of Applied Management Accounting Research, 5(1), 39-58.http://www.divaportal.org/smash/ record.jsf?pid=diva2\%3A984539\&dswid=7678

Mardiasmo. (2018). Akuntansi Sektor Publik (Edisi Terbaru). Yogyakarta: ANDI.

Marginson, D., McAulay, L., Roush, M., dan Van, T. Zijil. (2009). Performance Measures and Short-Termism: An Exploratory Study. https:/ / doi.org/10.5070/p2wk5v

Maria dan Nahartyo, E. (2012). Influence Of Fairness Perception And Trust On Budgetary Slack: Study Experiment On Participatory Budgeting Context. Simposium Nasional Akuntansi XV Banjarmasin, (0156), 1-63. http:/ / pdeb.fe.ui.ac.id/?p=6365

Merchant, K. A. (1985). Budgeting and the propensity to create budgetary slack. Accounting, Organizations and Society, 201-210. https:// doi.org/https:/ / doi.org/10.1016/0361-3682(85)90016-9

Morgan, R. M., dan Hunt, S. D. (1994). The Commitmen-Trust Theory of Relationship Marketing. Journal of Marketing, 58(3), 20-38. https:// doi.org/https:/ / doi.org/10.1177/002224299405800302

Mulyadi. (2016). Sistem Informasi Akuntansi (Edisi 4). Jakarta: Salemba Empat.

Munandar, A., Shauki, E. R., dan Diyanty, V. (2019). The Role of Pay Scheme and Ethics Level for Decreasing Budgetary Slack: Experiment Setting. Advanced in Economics, Business and Management Research, 89(Apbec 2018), 5762.http://creativecommons.org/licenses/by-nc/4.0/

Murdijaningsih, T. (2003). Hubungan Antara Dua Konsekuensi Pengendalian Anggaran: Kelonggaran Anggaran dan Orientasi Manajerial Jangka Pendek.Thesis.(Universitas Diponegoro).http:/ / eprints.undip.ac.id/9935/

Novitasari, N., dan Wirama, D. (2016). Pengaruh Pengendalian Anggaran Pada Senjangan Anggaran Dan Orientasi Jangka Pendek Manajer. E-Jurnal Akuntansi Universitas Udayana, 15(3), 20242051.https://ojs.unud.ac.id/index.php/Akuntansi/article/view/17692 
Okafor, C. A., dan Otalor, J. I. (2018). Budget Participation And Budgetary Slack : Evidence From

Quoted. (April).https://www.researchgate.net/publication/332449067_budget_part icipa

tion_and_budgetary_slack_evidence_from_quoted_firms_in_nigeria

Özera, G., dan Yilmaz, E. (2011). Effects of Procedural Justice Perception, Budgetary Control Effectiveness and Ethical Work Climate on Propensity to Create Budgetary Slack. Business and Economics Research Journal, Vol. 2(4), 118. https://www.berjournal.com/effects-of-procedural-justice-perceptionbudgetary-control-effectiveness-and-ethical-work-climate-on-propensity-tocreate-budgetary-slack-2

Peters, R. G., Covello, V. T., dan McCallum, D. B. (1997). The Determinants Of Trust and Credibility in Environmental Risk Communication: An Empirical Study. Risk Analysis, 17(1), 43-54.https://doi.org/10.1111/j.15396924.1997.tb00842.x

Prawita, W., dan Wirasedana, I Wayan P. (2017). Gaya Kepimpinan dan Komitmen Organisasi Sebagai Pemoderasi Pengaruh Partisipasi Anggaran Pada Senjangan Anggaran. E-Jurnal Akuntansi Universitas Udayana, 19, 280310.https://ojs.unud.ac.id/index.php/Akuntansi/article/view/26280

Puspitha, D. M. A. P., dan Suardana, Ketut Alit. (2017). Faktor-faktor yang Menyebabkan Senjangan Anggraan di SKPD Kabupaten Karangasem Bali. E-Jurnal Akuntansi Universitas Udayana, 21(1), 800-829. Retrieved from https://ojs.unud.ac.id/index.php/Akuntansi/article/view/33999

Stede, W. A.Van Der. (2000). The Relationship Between Two Consequences Of Budgetary Controls: Budgetary Slack Creation And Managerial Short-Term Orientation. Accounting, Organizations and Society, 25(6), 609-622. https:/ / doi.org/10.1016/S0361-3682(99)00058-6

Sugiantari, N., dan Widanaputra, A. (2016). Pengaruh Idealisme, Relativisme, Dan Love of Money Pada Persepsi Mahasiswa Akuntansi Tentang Krisis Etika Akuntan. E-Jurnal Akuntansi Universitas Udayana, 17(3), 2474-2502. https://ojs.unud.ac.id/index.php/Akuntansi/article/view/23877

Suherman, I. P. W. N. P., dan Dewi, L. G. K. (2019). Kompensasi Memoderasi Pengaruh Partisipasi Anggaran Pada Budgetary Slack. E-Jurnal Akuntansi Universitas Udayana, 27(3), 2460-2486. https:/ / doi.org/https:/ / doi.org/10.24843/EJA.2019.v27.i03.p30

Sukayana, G. A., dan Putri, I G.A.M. Asri Dwija. (2019). Tri Hita Karana Culture And Organizational Commitments Moderate: Effect of Participation on Budgetary Slack. International Research Journal of Management, IT and Social Sciences, 6(4), 180-188. https:/ / doi.org/10.21744/irjmis.v6n4.676

Tresnanty, A., dan Widanaputra, A. (2015). Pengaruh Penganggaran Partisipatif Terhadap Senjangan Anggaran Dengan Kepercayaan Manajerial Sebagai Variabel Intervening. E-Jurnal Akuntansi Universitas Udayana, 13(1), 240258.https:/ / ojs.unud.ac.id/index.php/Akuntansi/article/view/12617

Victor, B., dan Cullen, J. B. (1988). The Organizational Bases of Ethical Work Climates. Administrative Science Quarterly, 33(1), 101. https:// doi.org/10.2307/2392857

Widanaputra, A. A., dan Mimba, N. P. S. H. (2014). The Influence of Participative 
Budgeting on Budgetary Slack in Composing Local Governments' Budget in Bali Province. Procedia - Social and Behavioral Sciences, 164(August), 391-396. https:// doi.org/10.1016/j.sbspro.2014.11.093

Wier, B., dan Patricia, D. C. (2000). Integrating Ethical Dimensions into a Model of Budgetary Slack Creation. Journal of Business Ethics, 28, 267-277. https://doi.org/10.1023/A:1006241902011

Yilmaz, E., dan Özer, G. (2011). The Effects Of Environmental Uncertainty And Budgetary Control Effectiveness on Propensity To Create Budgetary Slack In Public Sector. African Journal of Business Management, 5(22), 8902-8908. https:// doi.org/10.5897/ajbm11.344

Yılmaz, E., Özer, G., dan Günlük, M. (2014). Do Organizational Politics and Organizational Commitment Affect Budgetary Slack Creation in Public Organizations? Procedia - Social and Behavioral Sciences, 150, 241-250. https:// doi.org/10.1016/j.sbspro.2014.09.047

Young, S. M. (1985). Participative Budgeting: The Effects of Risk Aversion and Asymmetric Information on Budgetary Slack. Journal of Accounting Research, 23(2), 829. https:// doi.org/10.2307/2490840 